\title{
human adenoviruses role in ophthalmic pterygium formation
}

\author{
Mishar Kelishadi ${ }^{1}$; Mandana Kelishadi ${ }^{2}$; Abdolvahab Moradi ${ }^{1}$; Naeme Javid ${ }^{1}$; Masoud \\ Bazouri ${ }^{1}$; Alijan Tabarraei ${ }^{1, *}$ \\ 1 Infectious Diseases Research Center, Golestan University of Medical Sciences, Gorgan, IR Iran \\ ${ }^{2}$ Department of Ophthalmology, 5th Azar Hospital, Gorgan, IR Iran \\ ${ }^{*}$ Corresponding author: Alijan Tabarraei, Infectious Diseases Research Center, Golestan University of Medical Sciences, Gorgan, IR Iran. Tel: +98-1714422652, Fax: +98-1714440225, \\ E-mail: alijant@yahoo.com
}

Received: December 14, 2013; Revised: May 31, 2014; Accepted: June 8, 2014

\begin{abstract}
Background: Ophthalmic pterygium is a common benign lesion of unknown origin and the pathogenesis might be vision-threatening. This problem is often associated with exposure to solar light. Recent evidence suggests that potentially oncogenic viruses such as human papillomavirus and Epstein-Barr virus may be involved in the pathogenesis of pterygia. Expression of specific adenovirus genes such as E1A and $E 1 B$, which potentially have many functions, may contribute to their oncogenic activity as well as relevance to cellular immortalization. Objectives: For the first time, we aimed to investigate involvement of adenoviruses in pterygium formation.

Patients and Methods: Fifty tissue specimens of pterygium from patients undergoing pterygium surgery (as cases), 50 conjunctival swab samples from the same patients and 10 conjunctival biopsy specimens from individuals without pterygium such as patients undergoing cataract surgery (as controls) were analyzed for evidence of adenovirus infection with polymerase chain reaction using specific primers chosen from the moderately conserved region of the hexon gene. Furthermore, $\beta$-globin primers were used to access the quality of extracted DNA. Data was analyzed using SPSS (version 16) software.

Results: Of 50 patients, 20 were men and 30 women with mean age of $61.1 \pm 16.9$ years ranged between 22 and 85 years. All samples of pterygia had positive results for adenoviruses DNA with polymerase chain reaction, but none of the negative control groups displayed adenoviruses. The pterygium group and the control groups were $\beta$-globin positive. Direct sequencing of PCR products confirmed Adenovirus infection.

Conclusions: Adenoviruses might act as a possible cause of pterygium formation and other factors could play a synergistic role in the development. However, further larger studies are required to confirm this hypothesis.
\end{abstract}

Keywords: Adenoviruses Human; Pterygium; Polymerase Chain Reaction; Iran

\section{Background}

Pterygium is a common benign lesion of corneo-conjunctival limbus of unknown origin (1) and the pathogenesis might be vision-threatening (2). Pterygium is found worldwide, most frequently occurring in sun-exposed areas, in particular, in tropical countries (3). It is characterized by a fleshy and wing-shaped overgrowth of the conjunctiva, which is histologically followed by degenerative and hyperplastic changes in the conjunctival epithelium (2).

Although ultraviolet irradiation, wind and dust (4), genetic predisposition, chronic inflammation (5), viral infections such as human papillomavirus (HPV), EpsteinBarr virus (EBV), herpes simplex virus (HSV) and sometimes, simultaneous detection of these viruses have been suggested as the causative factor in the development of pterygium, experiments have been inconclusive $(5,6)$.

Detorakis et al. proposed a "two-hit" process of pterygium formation. The first hit is preexisting ultraviolet (UV)-related genetic damage and the second hit is an oncogenic event mediated by a viral agent (5). Several stud- ies proposed potential contribution of HPV in pterygium formation; however, the presence of HPV in pterygia varies widely from $0 \%$ to $100 \%$ in different geographic regions (7-11). Few studies reported the correlation between other viral infections and pterygia, due to low-level presence of these virus genomes in pterygia $(2,5,12,13)$.

\section{Objectives}

Expression of specific adenovirus genes such as E1A and $E 1 B$, which potentially have many functions, may contribute to their oncogenic activity as well as relevance to cellular immortalization. We investigated, for the first time, the presence of adenoviruses in pterygia in Iran, a country with a high prevalence of pterygium.

\section{Patients and Methods}

\subsection{Patient Samples}

This cross-sectional study was performed in the Department of Ophthalmology and Virology in Golestan Univer-

Copyright (C) 2015, Ahvaz Jundishapur University of Medical Sciences. This is an open-access article distributed under the terms of the Creative Commons Attribution-NonCommercial 4.0 International License (http://creativecommons.org/licenses/by-nc/4.0/) which permits copy and redistribute the material just in noncommercial usages, provided the original work is properly cited. 
Kelishadi M et al.

sity of Medical Sciences, Gorgan, Iran, between February 2011 and May 2013. The study and sampling were approved by the Ethics Approval Committee of the Faculty of Medical Sciences, Golestan University of Medical Sciences with code of practice 262790101806, in January 2011, and informed consent was obtained from patients. The study group included 50 cases of surgically excised pterygium and the group of 50 conjunctival swab samples of the same patients and 10 conjunctival biopsy specimens of individuals who were undergoing cataract surgery but exhibited no characteristics of pterygium, as controls, in 5th Azar Hospital of Gorgan, Iran. The samples stored at $-70^{\circ} \mathrm{C}$ until processing.

\subsection{Deoxyribonucleic Acid Extraction}

Briefly, all sections were used for DNA extraction using a QIAamp DNA Mini kit (Qiagen, Valencia, CA). The experiments were performed according to the manufacturer's instructions.

\subsection{Polymerase Chain Reaction}

First, $\beta$-globin primers were used to access the quality of extracted DNA and exclude false negative results. Then PCR amplification for the presence of adenovirus DNA was performed with primers ADHEX1F (5'-CAA CAC CTA YGA STA CAT GAA-3'; NCBI Reference Sequence: KF268198.1) and ADHEX1R (5'-KAT GGG GTA RAG CAT GTT-3'; NCBI Reference Sequence: KF268200.1; 475 bp) from the moderately conserved region (amino acids 540 to 662) of the hexon gene that are sufficient to allow HAdV speciation and in most cases, serotype identification $(14,15)$, in a $50 \mu \mathrm{L}$ reaction volume, containing $5 \mu \mathrm{L}$ extracted DNA sample, 20 pmol of each of the universal forward and reverse primers, $0.5 \mathrm{mM}$ of each deoxynucleotide (dNTP; Genet Bio [A type], Nonsan, Republic of Korea), $2.5 \mathrm{U}$ of Taq DNA polymerase (Genet Bio [A type]), $2 \mathrm{mM} \mathrm{MgCl}_{2}$ (Genet Bio [A type]) and $5 \mu \mathrm{L}$ 10X PCR reaction buffer (Genet Bio [A type]). All standard precautions were followed to prevent PCR contamination and positive and negative controls were included with each run. Reactions were performed in a Peq Lab thermal cycler (Primus Advanced 96 thermal cycler), programmed as follows: $95^{\circ} \mathrm{C}$ for 5 minutes, 30 cycles of $94^{\circ} \mathrm{C}$ for 1 minute, $50^{\circ} \mathrm{C}$ for 1 minute and $68^{\circ} \mathrm{C}$ for 1 minute; and $72^{\circ} \mathrm{C}$ for 3 minutes.

\subsection{Detection}

PCR amplicons were visualized with $2 \%$ agarose gel electrophoresis.

\section{Results}

The study groups included 50 cases of surgically excised pterygium (20 men, 30 women, mean age: $61.1 \pm 16.9$ years, age range 22 to 85 years) (as cases) and 10 conjunctival biopsy specimens of individuals who underwent cataract surgery but exhibited no characteristics of pte- rygium ( 6 males, 4 females, mean age: $58.9 \pm 15.5$ years, age range: 19 to 70 years) (as control). As well, to search for persistent or latent infections with adenoviruses, 50 conjunctival swab samples from the first group were analyzed with polymerase chain reaction. All patients with pterygium had positive results for adenovirus DNA with PCR, but none of the negative control groups displayed adenoviruses (Figure 1). The pterygium groups and the control groups were $\beta$-globin positive. Direct sequencing of PCR products confirmed Adenovirus infection. Thirteen patients had bilateral pterygia. Forty-two pterygia were primary lesions and eight were postoperative recurrent. The patients were clinically evaluated to grade the severity of their pterygia; 14 (28\%) were atrophic/grade 1,17 (34\%) were intermediate/grade 2 and 19 (38\%) were fleshy/grade 3. A family history of pterygium was found in two cases (4\%). Five positive cases (10\%) had a history of outdoor activities. Smoking history was found in seven (14\%) patients with pterygium. Forty-six (92\%) patients with pterygium and nine (90\%) individuals without pterygium (control group) had a history of red eye of unknown origin.

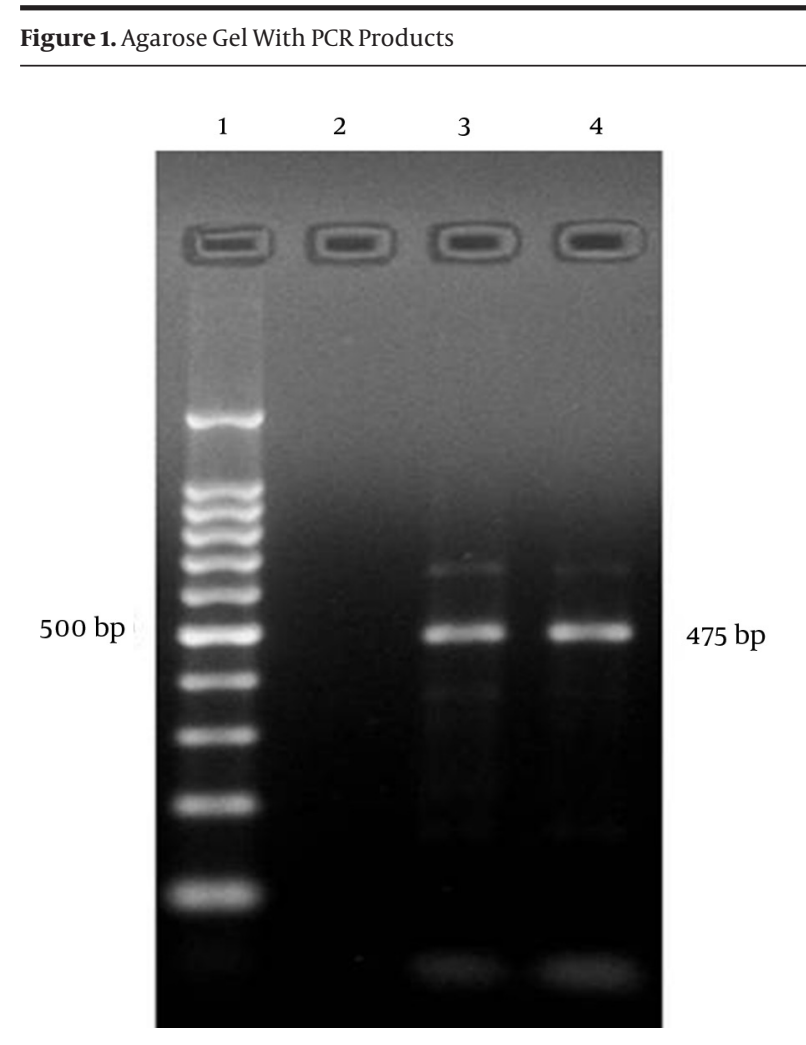

From left: lane 1: DNA ladder (100 bp), lane 2: negative control, lane 3: positive control, lane 4: ADV-positive specimen.

\section{Discussion}

Many theories have been advanced to explain how pterygia develops, but despite various studies, the definitive causative mechanism is still unknown (16). Uncontrolled 
cell proliferation, recurrence after surgical excision (up to $46 \%$ after seven years) $(2,8)$, abnormal levels of $\mathrm{p} 53$ protein (9), detection of loss of heterozygosity and presence of oncogenic viruses support the possible neoplastic nature of the lesion $(1,6)$. Epidemiological studies around the world have shown that pterygium prevalence rates range from $0.3 \%$ to $37.46 \%(17,18)$ and vary according to age $(5)$, geographic location $(3,4)$, inherited factors, sunlight exposure and activities with high UV exposure $(19,20)$.

However, stabilization, in particular, overexpression of p53 protein and disruption of the normal process of apoptosis can occur because of pterygium formation $(2,9)$. The tumor suppressor protein p53 has a short half-life and is normally present in low or undetectable levels within unstressed cells. p53 is essential for maintaining genomic stability after DNA damage. Because of DNA damage, p53 levels increase (21,22). p53 induces mitotic cell cycle arrest, thus providing time for a cell to repair its DNA before the next round of replication takes place (21). Mutations in the p53 gene are believed to lead to abnormal expression.

UV radiation and oncogenic viruses have been shown to be probable mutagenic factors for the $\mathrm{p} 53$ gene that lead to abnormal expression in the limbal basal stem of all pterygia and limbal tumors (23). Pterygia also develops in patients without direct exposure to sunshine; thus, other factors may also participate in pterygium pathogenesis $(2,4)$. Our finding implies the above explanation and is in contrast with the results of most previous studies that postulate occupations or activities with high UV exposure are associated with a risk of pterygium $(20,24)$.

No specific evidence for a pathogenic role of the reported virus infection in pterygium has been introduced. Although recent evidence suggests that potentially oncogenic viruses, such as HPV, HSV and EBV may be involved in the pathogenesis of pterygia, the results are still inconclusive $(5,6)$.

Dushku et al. (11) detected increased p53 in pterygium without evidence of HPV infection, leading the authors to postulate that overexpression of $\mathrm{p} 53$ protein in pterygium is affected by either hereditary factors or ultraviolet radiation $(2,3,9,11)$. In contrast, a study in Taiwan found that p53 inactivation might be linked with HPV infection in pterygium (22).

However, some authors suggested that UV-B radiation may activate viruses such as herpes and human papillomaviruses $(9,25)$. Transforming proteins produced by adenovirus propose that the virus may act as a contributing pathogenic factor. At present, there is no way to be certain how adenoviruses are involved in the development of pterygia, but the following possible explanations might suggest the role of this virus in the occurrence of lesion:

1) Multiple adenovirus early proteins (Ad E) such as E1A, E1B and E4orf6 proteins have been shown to affect the properties and half-life of $\mathrm{p} 53$ protein via different mechanisms (21), thus altering the normal biologic function of the p53 protein, which leads to increased changes in the genome (21). Why adenoviruses produce such several different pro- teins all causing repression of the transcriptional activity of p53 that might contribute to tumorigenesis is unclear. 2) The E1A and large E1B proteins inhibit transcription stimulation and repression of transcription by p53 (21). 3) The E1A protein causes stabilization of the p53 protein. 4) The E1A protein promotes cell proliferation and inhibits differentiation (25). 5) The small E1B protein inhibits p53-mediated apoptosis (21). 6) The E3 transcription unit encodes proteins that modulate the host immune response and all appear to involve immune evasion, resulting in their longterm survival $(26,27)$.

Epidemiological studies indicated that clinical course of adenoviral conjunctivitis varies from unapparent infection to severe conjunctivitis. Thus, we should consider the possibility of persistent or latent infections with adenoviruses in pterygium tissues (28).

In conclusion, because our entire sample of pterygia had positive result for adenoviruses, adenoviruses are a possible factor responsible for inducing pterygium and other factors might play a synergistic role in the development process. It may help appropriate treatment of pterygia and management. Larger studies in different geographic populations are needed to clarify the role of adenoviruses in pterygium formation.

\section{Acknowledgements}

We would like to thank the Infectious Disease Research Centre, Golestan University of Medical Sciences for continuous encouragement during this study and the Department of Ophthalmology at Gorgan 5th Azar Medical Center for providing valuable tissue specimen. We would like to thank Dr. Mohammad Ali Vakili for his valuable statistical comments.

\section{Funding/Support}

This project was supported by the Infectious Diseases Research Center, Golestan University of Medical Sciences (Grant No. 9008100183).

\section{Authors' Contributions}

Dr. Alijan Tabarraei contributed to project management and final approval of the study and writing the manuscript. Mishar Kelishadi contributed to design of the study and was involved in all steps of experimental work, manuscript preparation, interpretation of data and writing the manuscript. Mandana Kelishadi contributed to critical review and comments as an ophthalmologist and providing tissue specimen. Abdolvahab Moradi contributed to critical review and comments. Masoud Bazouri and Naeme Javid contributed to data collection and sampling.

\section{References}

1. Spandidos DA, Sourvinos G, Kiaris H, Tsamparlakis J. Microsatellite instability and loss of heterozygosity in human pterygia. $\mathrm{BrJ}$ Ophthalmol.1997;81(6):493-6.

2. Rodrigues FW, Arruda JT, Silva RE, Moura KK. TP53 gene expres- 
sion, codon 72 polymorphism and human papillomavirus DNA associated with pterygium. Genet Mol Res. 2008;7(4):1251-8.

3. Di Girolamo N. Association of human papilloma virus with pterygia and ocular-surface squamous neoplasia. Eye (Lond). 2012;26(2):202-11.

4. Sjo NC, von Buchwald C, Prause JU, Norrild B, Vinding T, Heegaard S. Human papillomavirus and pterygium. Is the virus a risk factor? BrJ Ophthalmol. 2007;91(8):1016-8.

5. Detorakis ET, Drakonaki EE, Spandidos DA. Molecular genetic alterations and viral presence in ophthalmic pterygium. Int J Mol Med. 2000;6(1):35-41.

6. Detorakis ET, Sourvinos G, Spandidos DA. Detection of herpes simplex virus and human papilloma virus in ophthalmic pterygium. Cornea. 2001;20(2):164-7.

7. Varinli S, Varinli I, Koksal Erkisi M, Doran F. Human papillomavirus in pterygium. Cent Afr J Med.1994;40(1):24-6.

8. Gallagher MJ, Giannoudis A, Herrington CS, Hiscott P. Human papillomavirus in pterygium. BrJ Ophthalmol. 2001;85(7):782-4.

9. Piras F, Moore PS, Ugalde J, Perra MT, Scarpa A, Sirigu P. Detection of human papillomavirus DNA in pterygia from different geographical regions. Br J Ophthalmol. 2003;87(7):864-6.

10. Chen KH, Hsu WM, Cheng CC, Li YS. Lack of human papillomavirus in pterygium of Chinese patients from Taiwan. Br J Ophthalmol.2003;87(8):1046-8.

11. Dushku N, Hatcher SL, Albert DM, Reid TW. p53 expression and relation to human papillomavirus infection in pingueculae, pterygia, and limbal tumors. Arch Ophthalmol. 1999;117(12):1593-9.

12. Takamura Y, Kubo E, Tsuzuki S, Akagi Y. Detection of human papillomavirus in pterygium and conjunctival papilloma by hybrid capture II and PCR assays. Eye (Lond). 2008;22(11):1442-5.

13. Guthoff R, Marx A, Stroebel P. No evidence for a pathogenic role of human papillomavirus infection in ocular surface squamous neoplasia in Germany. Curr Eye Res. 2009;34(8):666-71.

14. Casas I, Avellon A, Mosquera M, Jabado O, Echevarria JE, Campos $\mathrm{RH}$, et al. Molecular identification of adenoviruses in clinical samples by analyzing a partial hexon genomic region. J Clin $\mathrm{Mi}$ crobiol. 2005;43(12):6176-82.

15. Avellon A, Perez P, Aguilar JC, Lejarazu R, Echevarria JE. Rapid and sensitive diagnosis of human adenovirus infections by a generic polymerase chain reaction. J Virol Methods. 2001;92(2):113-20.
16. Schellini SA, Hoyama E, Shiratori CA, Sakamoto RH, Candeias JM. Lack of papillomavirus (HPV) in pterygia of a Brazilian sample. Arq Bras Oftalmol. 2006;69(4):519-21.

17. Zhong H, Cha X, Wei T, Lin X, Li X, Li J, et al. Prevalence of and risk factors for pterygium in rural adult chinese populations of the Bai nationality in Dali: the Yunnan Minority Eye Study. Invest Ophthalmol Vis Sci. 2012;53(10):6617-21.

18. Chen YF, Hsiao CH, Ngan KW, Yeung L, Tan HY, Yang KH, et al. Herpes simplex virus and pterygium in Taiwan. Cornea. 2008;27(3):311-3.

19. Panchapakesan J, Hourihan F, Mitchell P. Prevalence of pterygium and pinguecula: the Blue Mountains Eye Study. Aust N Z J Oph thalmol.1998;26 Suppl 1:S2-5.

20. McCarty CA, Fu CL, Taylor HR. Epidemiology of pterygium in Victoria, Australia. BrJ Ophthalmol. 2000;84(3):289-92.

21. Steegenga WT, van Laar T, Riteco N, Mandarino A, Shvarts A, van der Eb AJ, et al. Adenovirus E1A proteins inhibit activation of transcription by p53. Mol Cell Biol.1996;16(5):2101-9.

22. Tsai YY, Chang CC, Chiang CC, Yeh KT, Chen PL, Chang CH, et al. HPV infection and p53 inactivation in pterygium. Mol Vis. 2009;15:1092-7.

23. Reid TW, Dushku N. Does human papillomavirus cause pterygium? BrJ Ophthalmol. 2003;87(7):806-8.

24. Tano T, Ono K, Hiratsuka Y, Otani K, Sekiguchi M, Konno S, et al Prevalence of pterygium in a population in Northern Japan: the Locomotive Syndrome and Health Outcome in Aizu Cohort Study. Acta Ophthalmol. 2013;91(3):e232-6.

25. Spruance SL. Pathogenesis of herpes simplex labialis: experimental induction of lesions with UV light. J Clin Microbiol. 1985;22(3):366-8.

26. Chinnadurai G. Opposing oncogenic activities of small DNA tumor virus transforming proteins. Trends Microbiol. 2011;19(4):17483.

27. Robinson CM, Seto D, Jones MS, Dyer DW, Chodosh J. Molecular evolution of human species D adenoviruses. Infect Genet Evol. 2011;11(6):1208-17.

28. Kaneko H, Iida T, Ishiko H, Ohguchi T, Ariga T, Tagawa Y, et al. Analysis of the complete genome sequence of epidemic keratoconjunctivitis-related human adenovirus type 8, 19, 37 and a novel serotype. J Gen Virol. 2009;90(Pt 6):1471-6. 